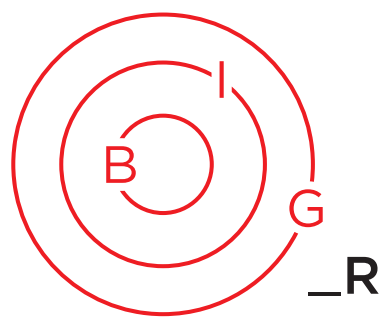

ESSAY

SPECIAL ISSUE

\title{
The Mexico-Guatemala Border During COVID-19: From Open Border to New Assemblage?
}

\author{
Edith Kauffer *
}

\begin{abstract}
The dynamics at the Mexican-Guatemalan border drastically changed from the beginning of the COVID-19 pandemic. This paper deals with these transformations and tries to evidence a new assemblage that has resulted. The rationale that prevailed until the beginning of 2020 between Mexico and Guatemala was a south-north selective open border derived from migratory controls applied to travelers according to their citizenship and their US or Canadian migratory status. From March until October, 2020 the pandemic gave birth to a new north-south rationale organized around a selective closure: the Guatemalan border was totally closed except to Guatemalans that were allowed to return to their country. On the Mexican side, communitarian, municipal, and local boundaries were established to curb the spread of COVID-19.
\end{abstract}

\section{Introduction}

Established at the end of the 19th century, the international boundary between Mexico and Guatemala was a model of a selective open border based on a southnorth rationale until March, 2020. The crossing gates controlled migrations from south to north depending selectively on the travelers' citizenship and their North American migratory status: Mexicans crossed the

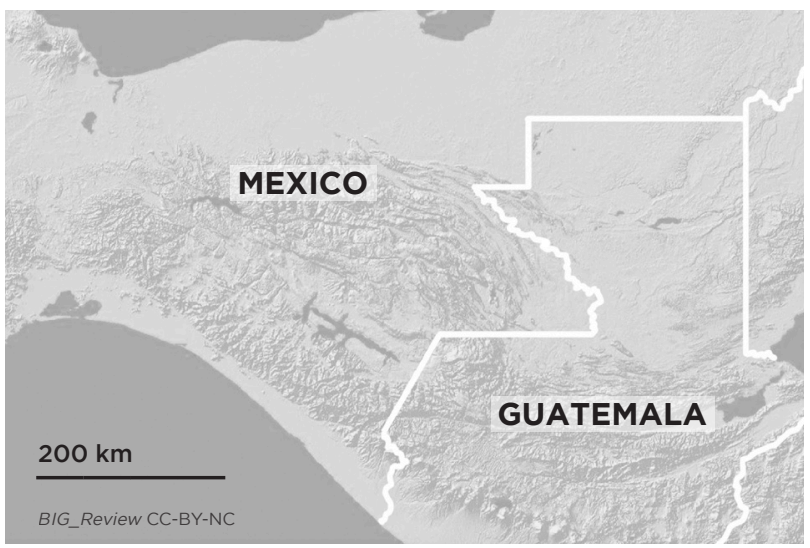

border in both direction without inconvenience while Guatemalans were subject to severe controls entering Mexico. The Mexican border was scarcely monitored by a few dispersed official crossings with migration and tax offices along an imaginary line of almost 956 kilometres. An entanglement of rivers and tropical forests characterizes the borderlands, clearly evidenced by a ten-metre wide deforestation area scattered with boundary monuments. In 2014, the Mexican State developed a series of sophisticated control and supervision points that concentrate federal offices to face migrations transiting from South and Central America to North America, built between 80 and 115 kilometres away from the border: three of these big installations were installed in the states of Chiapas and Tabasco (Kauffer 2020). Countless pathways supervised by local Mexican inhabitants shaped the border as a huge no-man's land that favored transboundary relations, human and animal movements, and an unregulated universe of multiple activities. In the absence of systematic controls, the south-north border was open but remained selective at the control points.

\footnotetext{
* Edith Kauffer, PhD in Political Science, Centro de Investigaciones y Estudios Superiores en Antropología Social (CIESAS)Sureste, Mexico. Contact: ekauffer@ciesas.edu.mx
} 
This selective open boundary shared with Guatemala has been a delicate issue, going back to the border's establishment in the 19th century, based on unfair negotiations, according to Guatemalan perspectives, and continued tensions throughout the 20th century. Security issues intensified when Guatemalan refugees arrived in Mexico at the beginning of the 1980s and settled close to the border. Furthermore, during the last three decades, migration from Central and South America, and other continents, crossed the border to reach North America, converting these borderlands into a US south-north control area (Coleman 2005). More recently, the migrant caravans that travelled from Central America to the United States in late 2018 revealed a complex phenomenon between a welcome openness policy at the end of 2018 followed by a strict closure from 2019 onwards. ${ }^{1}$ Thus, Central Americans were first welcomed without migratory controls and received public and private aid to enter and cross Mexico to reach the US border until the Mexican government was pushed by the US executive to change policy. That event evidences how the selective open border also follows international politics imperatives.

The COVID-19 pandemic changed the dynamics of the Mexican-Guatemalan border in at least two important ways. First, the traditional rationale tried to adapt to new circumstances. Second, on the Mexican side of the border, multiple internal borders began to appear. These new realities shape a new assemblage of borders, the focus of this paper.

\section{The "Borders" Between Mexico and Guatemala: Selective Openness}

Shortly after the World Health Organization (WHO) declared COVID-19 a pandemic in March, 2020, Mexico's three neighbor countries unilaterally closed their borders: Guatemala on March, 17th, and Belize and the United States on March 21st, 2020. In stark contrast to many countries in the world, Mexico did not close its borders. This strict Guatemalan closure was repeatedly extended between March and September 18, when the government announced the re-opening of its borders.

Traditionally, the difficulty of crossing borders into North America from south to north depended on the travelers' citizenship. Among those borders, the Mexico-Guatemala border was the most porous of the region, though the experience of crossing could be totally different depending on the place, the direction, and the chosen modality of crossing, whether at an official gate or through an informal pathway.

Two rivers, originating in Guatemala, define 59 percent of the international border. On the Pacific coast, the Suchiate River divides the countries for 77 kilometres before connecting with the Pacific Ocean (Kauffer 2017). The Usumacinta River flows south to north, along 363 kilometres in Guatemala, where it is known as Salinas-La Pasión River, then it delineates 365 kilometres of the international border, and converts into a state border in Mexico between Chiapas and Tabasco before reaching the Gulf of Mexico 386 kilometres downstream (Kauffer 2013). The land border, in some cases, passes through small urban areas with twin communities, such as Ciudad Hidalgo (Mexico) and Tecún Uman (Guatemala), or connects rural localities, such as Tziscao (Mexico) and El Quetzal (Guatemala), but the main part of the boundary consists of small rural and isolated localities, tropical forests such as the Lacandona Jungle (Mexico) and the Maya Biosphere (Guatemala) and other protected areas.

In this context, the interactions with the border are multiple. A deep empirical difference deals with the existence of a legal, formal and an established border in contrast with an informal boundary, experienced at local scale.

Only eight official inspection stations are distributed along the 956 kilometres and, according to the Mexican Exterior Relations Secretary (SRE 2013), there are 56 unofficial crossings accessible by car. Today, there are probably more, because of ongoing deforestation and new drug routes. The number of footways is impossible to evaluate.

To cross the border from Mexico (north) to Guatemala (south), they are various possibilities depending on the objective: visiting friends or shopping on the other side, for example to El Ceibo, La Mesilla, and Tecún Unám, Guatemala, was possible crossing through official crossings with a visa to enter Guatemala or with a Mexican ID. It was also possible to avoid official monitoring by walking through paths located a few metres away or using the informal border services to transport merchandise without custom controls. Once in the proximity of the border, the transboundary service providers are always ready to negotiate. In more remote areas, where there are no official crossings, the border is invisible except for white signposts and the ten-metre strip of deforestation that indicates the political delimitation.

To cross the border from Guatemala (south) to Mexico (north), the modalities are the same as the former but the official inspection stations on the Mexican side are more strictly controlled, especially if the traveler does not hold a Mexican ID, a US, Canadian, or European passport, or a US Visa. Mexican citizens must typically register, although it depends on the crossing point, and only need basic ID. Foreigners must fill documents and queue up. Finally, there also exist the option of using the nearby unofficial paths or dealing with the informal transboundary service providers for crossing.

Along the border, informal ways are located in rural localities that organized their own community customs 
and "tax" services according to volumes and types of merchandise. Berke Galemba (2018) studied one of the most organized and famous places where big trailers arrived and locals organized transfers to Mexican trucks. The number of informal points increased during the last fifteen years where local populations controlled the crossings, revealing an interesting phenomenon of privatization of the border. Finally, where no official or local crossing points exist, crossing was often easy, and sometimes the faster way to travel between two places in Guatemala was crossing through Mexico.

At official crossing points, informal modalities are tolerated and completely observable during fieldwork at horizontal scale -parallel transboundary unofficial paths- as well as at vertical scale like the official crossings through the bridges on the Suchiate River and the informal ones under them walking or biking in the river or by balsas -small boats made with trailer tubes and wooden plank or trunks- that coexist with the Mexican government's inspection stations.

Transboundary communication across the Usumacinta River depends on local inhabitants because there is no bridge and only one official inspection station in the Mundo Maya (Maya World) tourism route. Nevertheless, besides people and merchandise, cattle and also sometimes cars, can be observed navigating the biggest river of Mexico, Guatemala and Central America.

The south-north rationale that defines the traditional dynamics of the border is established to control above all, migration. Selective openness on this border depends on the direction, passport holder's citizenship, crossing points and the decision to cross formally or not. Completely open from north to south but characterized by a selective openness form south to north, the Mexican-Guatemalan border and the GuatemalanMexican border shape two different experiences. Consequently, the south-north rationale in addition to the above-described modalities delineate multiple "borders" according to individual and collective experiences along this imaginary line.

\section{COVID-19 and New Assemblage: Inverted Rationale and New Internal Borders}

Based on previous fieldwork (1994 to March 4th, 2020) and current online research, the paper now explores how the pre-COVID-19 borders based on a selective openness converted themselves into a new assemblage.

The closure of the border by Guatemala was the first event that changed the logics of the former selective open border. From this event and until the end of the critical situation when the border opened in mid-September, COVID-19 was considered as an external threat. Guatemalan borders were totally closed, air connections interrupted, and only nationals were allowed to enter the country by land. A sanitary filter was organized at the formal border crossings and people sent to quarantine if they were considered potentially infectious. To control the entries and impose this new north-south rationale, the military and the National Police were sent to the Guatemalan borders, especially to the official inspection points.

At the end of May, the Guatemalan president declared that Mexico, that had not closed its borders, was responsible for the increasing numbers of infection in Guatemala. Some days later, the Guatemalan government opened a new monitoring point in Los Ingenieros on the border that corresponds to an existing Mexican official crossing located in a rural remote area, Frontera Orizaba, probably to increase the control. Controlling people's movements was the new north-south rationale applied to the pandemic as a selective border closure policy.

To cross into Mexico during the Guatemalan border closure, the official inspection point included sanitary filters consisting of taking temperature and sharing information about social distancing, that were added to the other requirements about documentation according to the crosser's citizenship. Inside Mexico, some mayors closed the borders of their municipalities to counteract risks associated with the openness of the Mexican international border.

The idea of the external origin of the contagion at local scale has been a powerful motivator to contain the pandemic in Mexico. Agrarian communities, small localities located along the international border, as well as municipalities, decided to close entry to outsiders as well as imposing mobility restrictions on their inhabitants. Thus, tourism-oriented communities closed the door to tourism and imposed quarantine on returned residents from the US, the northern border of Mexico, the Riviera Maya, and from the cities. In Chiapas, three bordering municipalities among 18 haven't officially registered any cases of COVID-19 during the first five months of the pandemic (March-July). For example, the municipality of Las Margaritas was closed on May 17, by the mayor due to the increasing number of COVID-19 cases in the neighboring Ocosingo, the most extended municipality of the whole border in Chiapas. As a matter of fact, Ocosingo had been unsuccessfully closed from April 14, 2020. The bordering state of Tabasco, one of the most affected by the epidemic at national scale in Mexico decided to put sanitary filters -consisting in temperature tests and restricting the people's mobility between municipalities to "essential reasons"- to control the expansion of the illness throughout its territory.

These internal borders were organized with the participation of the local population who controlled entries and exits from the localities and in some cases, 
they were linked with political organizations. In Chiapas, the EZLN (National Liberation Zapatista Army) announced the closure of its affiliated communities as well as all its meeting centers on March 16.

Eventually, the informal transboundary dynamics followed their own way although most of them have been restricted by the new international and local borders above mentioned and by the boundaries that have resulted from the real and imagined threats personified by foreigners, migrants, and tourists. Nevertheless, transboundary informal crossings increased during the summer 2020, especially to evade Guatemalan military control. For example, men carrying merchandise and people crossing the waters of the Suchiate River were observed as a result of the prohibition of the balsas.

At national scale in Guatemala and at local scale in Mexico, the boundaries appeared to be the main strategy for containing the transboundary COVID-19 expansion: a strategy to control freedom of movement and transits, including quarantine, without clear health policy measures. During the closure, Guatemalan citizens were only tested for temperature and when the international borders opened, all the travelers were asked to present a negative PCR test processed within 72 hours prior to crossing and to wear masks.

After six months of closure, the situation on the bordering municipalities in both countries evidenced that a single strategy of movement control, lacking a clear articulation of transboundary health policy, has not impeded the transmission of the novel coronavirus; in October 2020, the sole exception in the borderlands is one municipality of Chiapas, Maravilla Tenejapa, that has not officially registered any case of COVID-19 during the first phase of the pandemic.

\section{Conclusion}

The border between Mexico and Guatemala during COVID-19 times presented an apparent new dynamic that combined a traditional selective south-north openness with a selective north-south closure related to the pandemic. Nevertheless, while the traditional openness is defined by migrations, the closure was supposed to be established to control the pandemic but without a specific health-oriented rationale.

In this dual border characterized by formal and informal crossing points, the Guatemalan closure directly concerned the control stations while transboundary movements were supposed to continue. During the first weeks, transboundary activities were reduced but later, an increased phenomenon linked with new informal modalities appeared to counteract the new transboundary north-south conditions. Furthermore, this emerging assemblage of old and new local and international boundaries focused on the control of people's mobility clearly attests to the entanglement of the traditional south-north rationale with north-south and local dynamics enforced by the novel coronavirus. In the Guatemalan-Mexican borderlands, the logics of establishing borders to control the crossings of the people was extended to the COVID pandemic to design a new assemblage in which transboundary health issues followed the traditional south-north rationale: a selective control of humans merged with ineffective results in containment.

\section{Note}

1 It was impossible to travel to the border to collect direct information for this paper: fieldwork activities were interrupted by the pandemic in mid-March, 2020, and they will not be officially able to restart until January, 2021. As the paper evidences, access to villages was canceled and a prohibition on fieldwork was directed from my research center. Research was based on secondary sources from Mexican and Guatemalan media, a detailed review of enacted Guatemalan executive ordinances, the Guatemalan Congress Agreements and Ordinances and the National Guidelines from the Ministry of Health and Social Assistance, from March to September, 2020. Due to the scarcity of Guatemalan information during the first months, I contacted Guatemalan colleagues in order to confirm some data and to be aware of new publications. It was not possible to access data about the numbers of infections and deaths in the Guatemalan borderlands until September, 2020.

\section{Works Cited}

Berke Galemba, Rebecca. 2018. Contraband Corridor. Making a Living at the Mexico-Guatemala Border. Stanford: Stanford University Press.

Coleman, Michael. 2005. "U.S. Statecraft and the U.S.-Mexico Border as Security/Economy Nexus". Political Geography 24(2): 185-209. https://doi.org/10.1016/j.polgeo.2004.09.016

Kauffer, Edith. 2013. "Represas en la cuenca transfronteriza del río Usumacinta. ¿Un conflicto crónico?” In Edith Kauffer (ed.) Cuencas en Tabasco: una vision a contracorriente. Mexico: CIESAS. 01-132.

Kauffer, Edith. 2017. "Contrasting Water Securities: The Mexican State Facing Downstream Stakeholders in the Suchiate Transboundary River Basin". International Journal of Water Resources Development 35(1): 30-48. https://doi.org/10.1080 /07900627.2017.1393400

Kauffer, Edith. 2020. "La frontera México-Guatemala en el prisma de las fronteridades (borderities) múltiples. Un acercamiento preliminar". In Alberto Hernández Hernández (ed.) Puentes que unen y muros que separan: fronter-ización, securitización y procesos de cambio en las fronteras de México y Brasil. Tijuana: El Colegio de la Frontera Norte; Brasil: Universidade Federal de Mato Grosso do Sul (UFMS). 195-212.

Secretaría de Relaciones Exteriores (SRE). 2013. Diagnóstico General de la Frontera entre México y Guatemala. Mexico: SRE. 